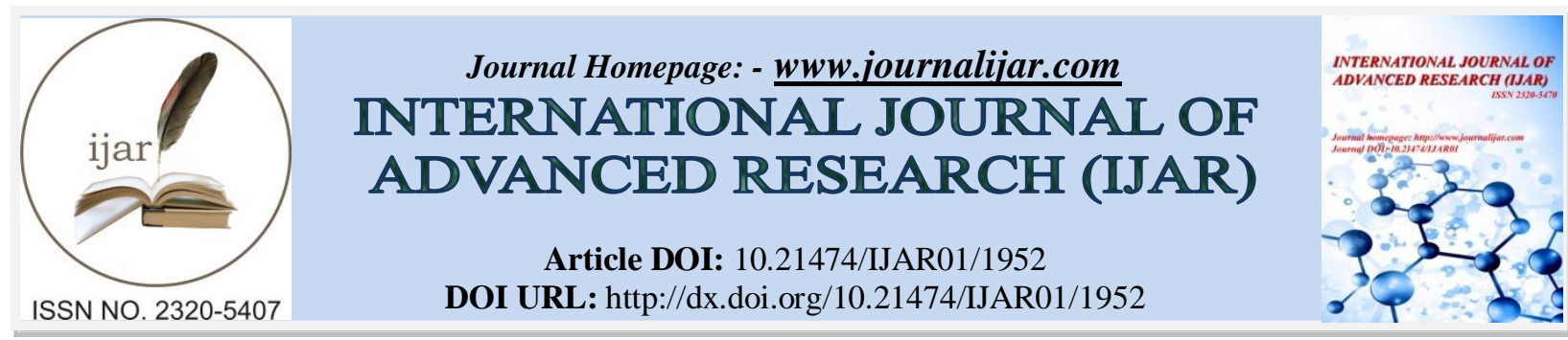

RESEARCH ARTICLE

\title{
IMPACT OF MINING ON SURFACE WATER QUALITY IN THE WESTERN PART OF SANDUR SCHIST BELT, KARNATAKA, INDIA - A PRELIMINARY INVESTIGATION
}

\author{
G.V. Gaonkar ${ }^{*}$, J.T. Gudagur ${ }^{1}$ and T.K. Lakkundi ${ }^{2}$.
}

1. Department of Geology, Karnatak Science College, Dharwad.

2. Department of Geology, Arba Minch University, Ethiopia.

\section{Manuscript Info}

Manuscript History

Received: 12 August 2016

Final Accepted: 22 September 2016

Published: October 2016

Key words:-

Water quality, Mining, Iron,

Environmental Impact, Sandur Schist Belt.

\section{Abstract}

Open cast mining has several impacts on the surrounding environment. One of the adverse impacts on the environment is in the form of pollution of water resource which can be attributed to blatant violation of environmental regulations and, unscientific, rampant and erroneous mining- and dumping-practices. Study of water quality in and around the mining area is critical for understanding the possible impacts and, to take adequate precautionary and corrective measures. Surface water samples from 18 locations were collected at the end of rainy season from the study area and preference is given to the locations near to the mining belt. Results indicated that the concentration of iron in all the sampled surface water bodies exceeds the guideline value of World Health Organization proving the impact of mining and allied practices on surface water resources.

Copy Right, IJAR, 2016,. All rights reserved.

\section{Introduction:-}

Management of ore and Over/Side/Inter Burden in the mining activity is a challenging task and requires systematic approach in handling. Unplanned and accelerated production by violating the concerned Rules and Regulations and partial implementation/unscientific execution of Environment Management System results in environmental pollution. Monitoring of water quality in the mining area as well as in the surrounding buffer zone is very important for impact assessment and to prepare management plan. Thus, surface water samples from 18 locations were collected at the end of rainy season in the year 2014.

The area selected for the present investigation forms a small part of the western region of the mining-intensive Sandur Schist Belt. The eastern flank of this area is a hilly terrain while the central and western parts are gently sloping to plain areas. Surface water bodies in the study area are in the form of natural ponds/lakes, an artificial reservoir in the form of backwaters of a dam across River Tungabhadra, streams and, artificially formed large pits formed due to open-pit mining and erosion. The run-off from the mines including the dump-sites results in the deposition of fine-silt in these water bodies. Water from these water bodies is used by humans, livestock and wild animals for different purposes including drinking and domestic purposes.

Vegetation occurring in the study area belongs to Southern Tropical Dry Deciduous Forests-type according to Champion and Seth Classification of forest types of India, 1968 (Indian Council of Forestry Research and Education, 2013). The study area falls under the mixed deciduous sub-classification. The majority of the trees are 
leafless during the dry months. The flowering and fruiting are generally far advanced before the first flush of new leaves appears with the showers in April - May.

\section{Study Area:-}

The study area is located in a part of western region of Sandur Schist Belt, Bellary District, Karnataka State between latitudes $14^{\circ} 58^{\prime} 35^{\prime \prime} \mathrm{N}$ to $15^{\circ} 13^{\prime} 45^{\prime \prime} \mathrm{N}$ and longitudes $76^{\circ} 15^{\prime} 00^{\prime \prime} \mathrm{E}$ to $76^{\circ} 30^{\prime} 00^{\prime \prime} \mathrm{E}$ [Survey of India toposheets numbered 57 A/8 (D43E8) and 57 B/5 (D43K5)] (Fig. 1).

Study area comprises of hills and plane lands. Eastern segment of the study area has hilly terrain represented by the Sandur Schist Belt having several mining leases for Iron and Manganese Ores (Fig. 2) and western segment is a plateau with granitic terrain. The lithological units include granitic gneiss, younger granite, quartzite, migmatites and metavolcanics.

Most part of the study area is accessible through a network of all-weather roads, both metalled- and unmetalledroads. However, entry to mining areas is either restricted or denied especially since this study involves impact of mining on the water resources.

The area experiences a semi-arid type climate with dry and hot summer. The maximum temperature is experienced during May and the minimum during December month in general. Temperature varies between $22^{\circ} \mathrm{C}$ and $43^{\circ} \mathrm{C}$ and the relative humidity of the region varies from $38 \%$ to $95 \%$. The climate is influenced by South-West and NorthEast monsoons. The average annual rainfall in the area is $870.7 \mathrm{~mm}$. It receives about $60.22 \%$ of the annual rainfall during South-West monsoon (June-September), 22.21\% during North-East monsoon (October-November) and balance $17.57 \%$ of rainfall occurs as sporadic in other months of the year (Indian Council of Forestry Research and Education, 2012).

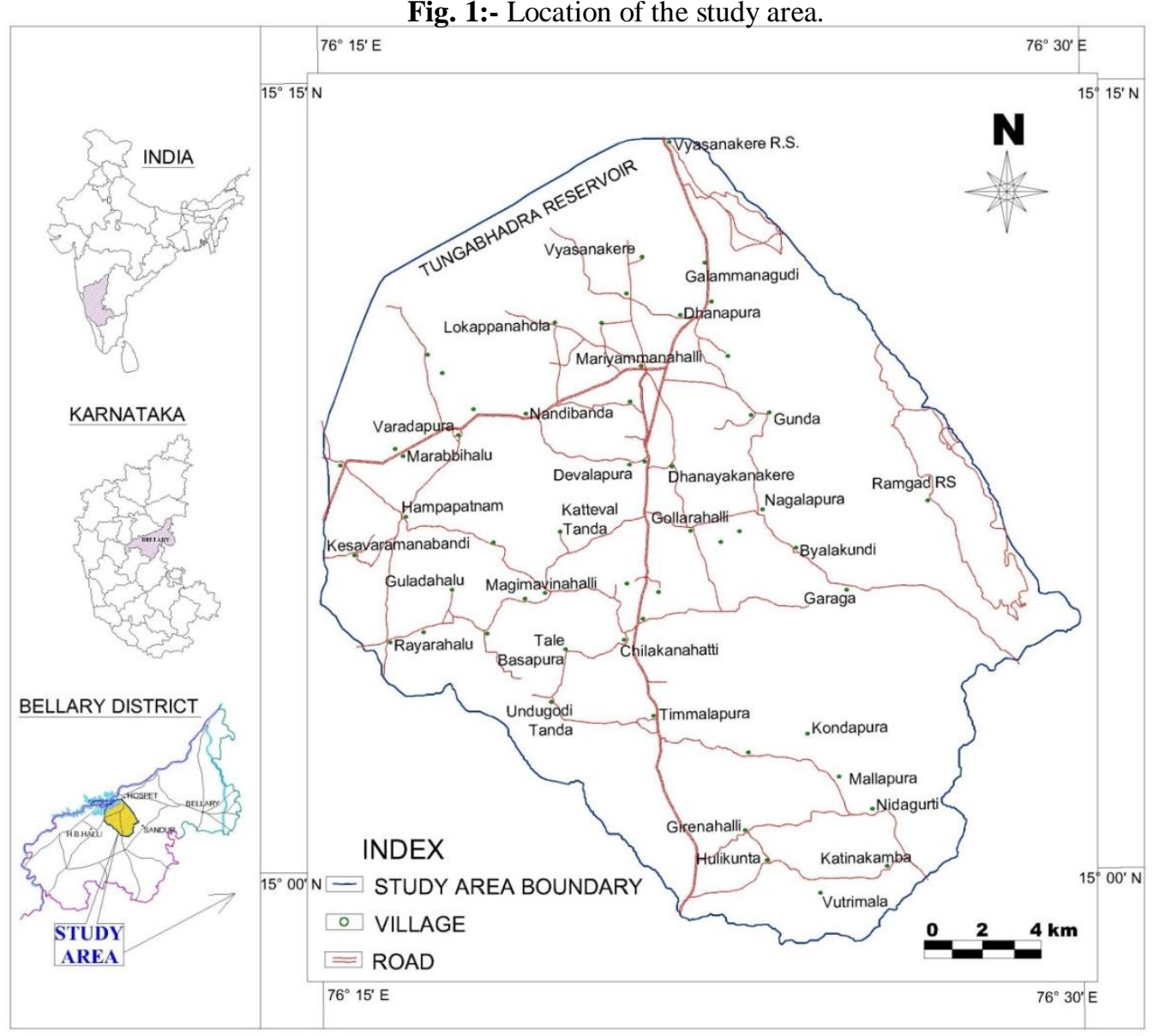




\section{Materials and Methods:-}

Since the study is concerned about the impact of iron- and manganese-ore mining on surface water resources, part of the Sandur Schist Belt within the study area having several mining leases and part of the area west of the schist belt (i.e. eastern half of the study area) is given preference while collecting the water samples.

Representative surface water samples from 18 locations (Fig. 2) were collected at the end of the monsoon season in 2014 from those parts of the study area where the chances of effect of ores and gangue on surface water resources are predominantly higher. These areas include hill slopes and foothills of Sandur schist belt and, the relatively flat terrain west of the schist belt (i.e. eastern half of the study area) into which the surface runoff will be flowing carrying along with it the products of mining.

Samples were collected in one liter polythene cans after thoroughly washing them with the water to be collected. Before collecting, samples were filtered so as to remove the suspended matter. Sample locations were recorded using a GPS-receiver.

Onsite measurements included measurement of water sample temperature, $\mathrm{pH}$ and electrical conductivity. Temperature was measured using a digital thermometer while $\mathrm{pH}$ and conductivity were measured using hand-held $\mathrm{pH}$ and conductivity pens of $\mathrm{HACH}$ make. Other parameters viz. Calcium $\left(\mathrm{Ca}^{2+}\right)$, Magnesium $\left(\mathrm{Mg}^{2+}\right)$, Sodium $\left(\mathrm{Na}^{+}\right)$, Potassium $\left(\mathrm{K}^{+}\right)$, Carbonate $\left(\mathrm{CO}_{3}{ }^{-}\right)$, Bicarbonate $\left(\mathrm{HCO}_{3}{ }^{-}\right)$, Chloride $\left(\mathrm{Cl}^{-}\right)$, Nitrate $\left(\mathrm{NO}_{3}^{-}\right)$, Sulphate $\left(\mathrm{SO}_{4}{ }^{2-}\right)$, Iron $(\mathrm{Fe})$, Manganese $(\mathrm{Mn})$, Fluoride $\left(\mathrm{F}^{-}\right)$and Total Hardness $(\mathrm{TH})$ were analyzed in the laboratory following the standard procedures as given by APHA $(1985,1998)$ and IS 3025.

Fig 2:- Location of water samples collected and the mining leases within the study area

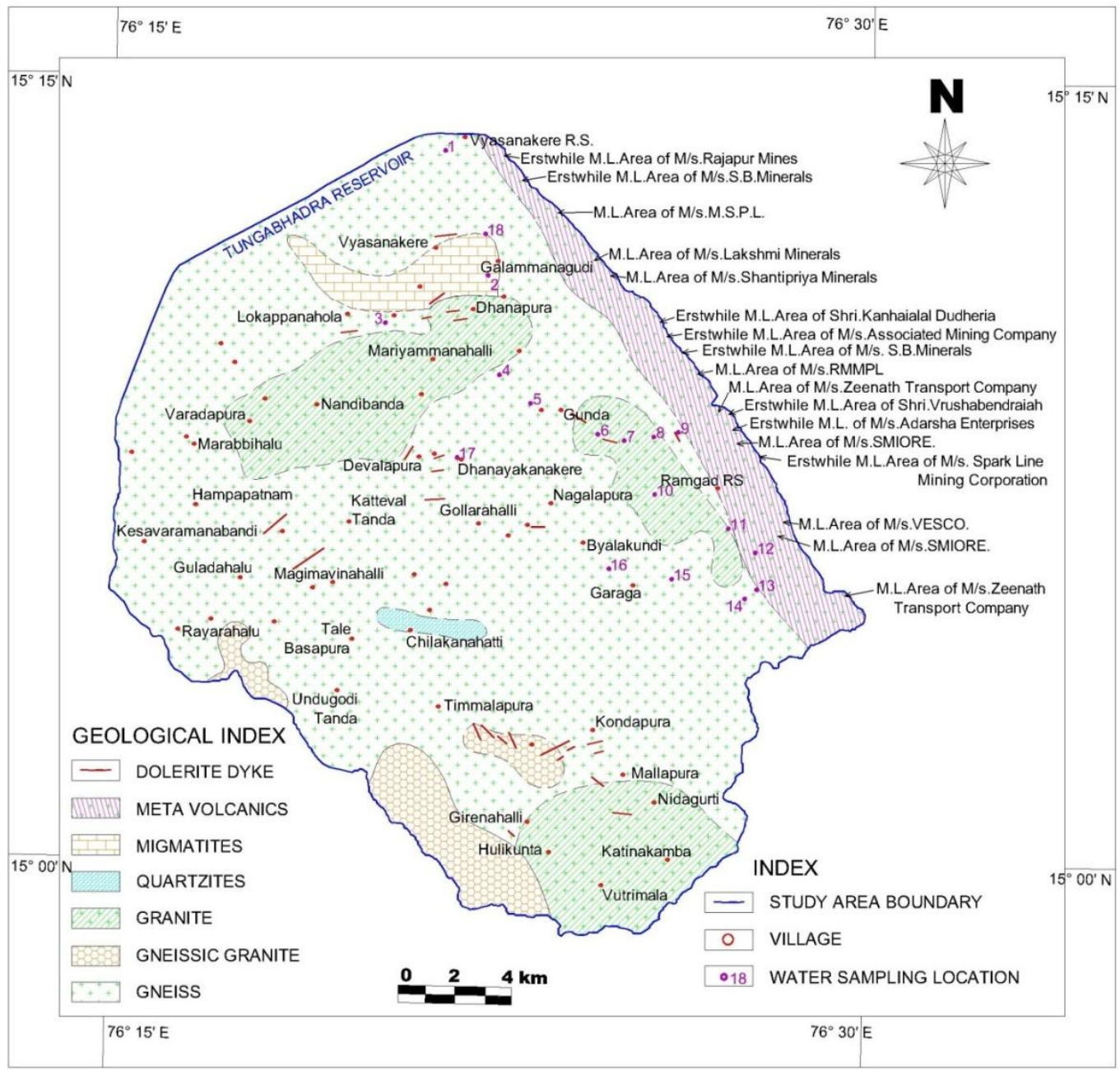




\section{Results and Discussions:-}

Results of the partial physico-chemical analysis of 18 representative water samples from the study area are presented in Table 1.

Table 1:- Results of partial physico-chemical analyses of water samples (Monsoon-2014)

\begin{tabular}{|c|c|c|c|c|c|c|c|c|c|c|c|c|c|c|c|c|c|c|}
\hline \multirow{2}{*}{$\begin{array}{l}\text { SI. } \\
\text { No. }\end{array}$} & \multirow[t]{2}{*}{ Location } & \multirow{2}{*}{$\begin{array}{l}\text { Sample } \\
\text { source }\end{array}$} & \multicolumn{16}{|c|}{ Parameters } \\
\hline & & & EC & pH & TH & TDS & $\mathbf{C a}$ & Mg & $\mathbf{N a}$ & $\mathbf{K}$ & $\mathrm{CO}_{3}$ & $\mathrm{HCO}$ & $\mathrm{SO}_{4}$ & $\mathrm{Cl}$ & $\mathrm{NO}_{3}$ & $\mathbf{F}$ & $\mathbf{F e}$ & Mn \\
\hline 1 & T.B.Dam (North) & $\mathrm{D}$ & 121 & 7.89 & 30 & 78 & 7.2 & 3.0 & 9.2 & 3.0 & $<2$ & 40 & 4.6 & 14.0 & 6.7 & BDL & 0.40 & 0.04 \\
\hline 2 & Hanumanahalli & $\mathrm{CD}$ & 221 & 7.70 & 44 & 143 & 9.6 & 4.8 & 28 & 5.0 & $<2$ & 76 & 9.7 & 20.0 & 4.7 & 0.46 & 0.18 & BDL \\
\hline 3 & Ayyanahalli & $\mathrm{T}$ & 610 & 8.19 & 85 & 393 & 14.0 & $\mid 12.0$ & 90 & 12 & 20 & 75 & 24 & $\begin{array}{c}122 . \\
0\end{array}$ & 3.3 & 0.21 & 0.25 & 0.04 \\
\hline 4 & $\begin{array}{l}\text { BMM Factory } \\
\text { backside }\end{array}$ & $\mathrm{T}$ & 160 & \begin{tabular}{|l|}
7.72 \\
\end{tabular} & 30 & 103 & 6.4 & 3.4 & 18 & 6.0 & $<2$ & 66 & 11 & 16.0 & 0.4 & 0.29 & 0.20 & 0.03 \\
\hline 5 & Check Dam & $\mathrm{CD}$ & 717 & 8.43 & 170 & \begin{tabular}{|l|}
462 \\
\end{tabular} & 44.0 & 14.5 & 78 & 12.0 & 45 & 90 & 31 & $\begin{array}{c}117 . \\
0\end{array}$ & 5.2 & 0.55 & 2.44 & 0.21 \\
\hline 6 & Hill S & $\mathrm{N}$ & 50 & 7.34 & 18 & 32 & 3.2 & 2.4 & 2.5 & 0.5 & $<2$ & 12 & 3.7 & 5.0 & 2.5 & 0.25 & 0.96 & BDL \\
\hline 7 & Hill & $\mathrm{N}$ & 120 & 7.35 & 38 & 77 & 8.8 & 3.8 & 9 & 1.8 & $<2$ & 22 & 5.2 & 18.0 & 8.8 & 0.14 & 0.13 & 0.04 \\
\hline 8 & Hill & $\mathrm{N}$ & 300 & 7.66 & 75 & 194 & 16 & 8.5 & 30 & 6.0 & 20 & 45 & 8.5 & 32.5 & 21.0 & 0.27 & 0.94 & 0.06 \\
\hline 9 & Hill & $\mathrm{N}$ & 175 & 7.55 & 30 & 113 & 6.4 & 3.4 & 23 & 4.5 & $<2$ & 62 & 9.7 & 13.0 & 7.6 & 0.11 & 0.20 & 0.04 \\
\hline 10 & Hill Slope & $\mathrm{N}$ & 287 & 7.43 & 76 & 185 & 20 & 6.3 & 28 & 0.8 & $<2$ & 22 & 29 & 47.0 & 16.0 & 0.27 & 0.65 & 0.05 \\
\hline 11 & $\begin{array}{l}\text { Hill Slope-Railway } \\
\text { Siding }\end{array}$ & $\mathrm{N}$ & 169 & 8.31 & 26 & 109 & 6.4 & 2.4 & 23 & 7.8 & $<2$ & 70 & 6.2 & 12.0 & 3.2 & 0.17 & 0.28 & BDL \\
\hline 12 & $\begin{array}{l}\text { Hill Slope- Railway } \\
\text { line }\end{array}$ & $\mathrm{N}$ & 134 & 8.22 & 20 & 86 & 4.0 & 2.4 & 18 & 1.5 & 8 & 38 & 4.6 & 4.0 & 3.0 & BDL & 0.63 & BDL \\
\hline 13 & $\begin{array}{l}\text { Hill Slope- Near } \\
\text { Ramgad }\end{array}$ & $\mathrm{N}$ & 152 & 7.63 & 24 & 98 & 6.4 & 2.0 & 20 & 1.8 & 8 & 42 & 4.7 & 14.0 & 3.5 & 0.19 & 0.45 & BDL \\
\hline 14 & $\begin{array}{l}\text { Hill Slope- } \\
\text { Yeshwanthngr }\end{array}$ & $\mathrm{N}$ & 145 & 7.65 & 28 & 94 & 6.4 & 2.9 & 21 & 0.7 & $<2$ & 54 & 4.8 & 13.0 & 4.8 & 0.15 & 0.31 & BDL \\
\hline 15 & Tank-Before Garag & $\mathrm{T}$ & 597 & 7.89 & 110 & 385 & 26 & 11.0 & 80 & 9.8 & 20 & 50 & 11 & $\begin{array}{c}150 . \\
0\end{array}$ & 3.8 & 0.13 & 1.02 & 0.083 \\
\hline 16 & Garag & $\mathrm{T}$ & 373 & 8.01 & 84 & 241 & 21 & 7.7 & 40 & 12.0 & 6 & 78 & 30 & 60 & 3.2 & 1.55 & 0.45 & BDL \\
\hline 17 & Dhanayakanakere & $\mathrm{T}$ & 262 & 8.27 & 74 & 169 & 23 & 6.8 & 17 & 4.5 & $<2$ & 98 & 13.8 & 23 & 4.8 & 0.18 & 0.89 & 0.03 \\
\hline 18 & T.B.Dam (South) & $\mathrm{D}$ & 132 & 7.88 & 38 & 85 & 9 & 3.8 & 12 & 1.5 & $<2$ & 28 & 9.5 & 18 & 4.7 & 1.22 & 1.07 & 0.03 \\
\hline & $\begin{array}{l}=\text { T.B.Dam, } \mathrm{CD}=\mathrm{C} \\
\text { Iardness as } \mathrm{CaCO} \\
\mathrm{O}_{3}=\text { Carbonates (m } \\
\mathrm{mg} / \mathrm{L}), \mathrm{F}=\text { Fluoride } \\
\mathrm{In}=0.02 \mathrm{mg} / \mathrm{L}) .\end{array}$ & 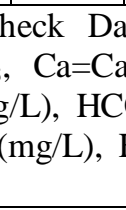 & & & & & & & & & & & & & (E) & ( & & es \\
\hline
\end{tabular}

Comparisons of the results with WHO (2004) Standards, IS:10500 Standards (BIS, 1991 and 2012) and CPCB Standards for drinking water are presented in Tables 2, 3 and 4 respectively. 
Table 2:- Comparison of results of partial physico-chemical analyses with WHO (2004) Standards.

\begin{tabular}{|c|c|c|c|c|c|c|c|}
\hline Sl. No. & \multirow{2}{*}{ Parameter } & \multicolumn{3}{|c|}{ Concentration of ions } & \multicolumn{2}{c|}{ WHO Standards (2004) } & $\begin{array}{c}\text { Percentage of } \\
\text { samples exceeding } \\
\text { permissible limit }\end{array}$ \\
\cline { 3 - 7 } & & Min. & Max. & Average & $\begin{array}{c}\text { Desirable } \\
\text { limit }\end{array}$ & $\begin{array}{c}\text { Permissible } \\
\text { limit }\end{array}$ & - \\
\hline 1 & $\mathrm{EC}$ & 50 & 717 & 262.50 & - & - & - \\
\hline 2 & $\mathrm{pH}$ & 7.34 & 8.43 & 7.84 & 6.5 & 8.5 & - \\
\hline 3 & $\mathrm{TH}$ & 18.0 & 170.0 & 55.56 & 100 & 500 & 5.56 \\
\hline 4 & $\mathrm{~F}$ & $\mathrm{BDL}$ & 1.55 & 0.38 & - & 1.5 & - \\
\hline 5 & $\mathrm{Fe}$ & 0.13 & 2.44 & 0.64 & - & 0.1 & - \\
\hline 6 & $\mathrm{Mn}$ & $\mathrm{BDL}$ & 0.21 & 0.06 & - & - & - \\
\hline 7 & $\mathrm{Ca}$ & 3.22 & 44.0 & 13.21 & 75 & 200 & - \\
\hline 8 & $\mathrm{Mg}$ & 2.0 & 14.50 & 5.62 & 50 & 150 & - \\
\hline 9 & $\mathrm{Na}$ & 2.50 & 90.0 & 30.37 & - & 200 & - \\
\hline 10 & $\mathrm{~K}$ & 0.50 & 12.0 & 5.07 & - & - & - \\
\hline 11 & $\mathrm{Cl}$ & 4.0 & 150 & 38.81 & 200 & 600 & - \\
\hline 12 & $\mathrm{SO}_{4}$ & 3.70 & 31.00 & 12.28 & 200 & 400 & - \\
\hline 13 & $\mathrm{NO}_{3}$ & 0.40 & 21.0 & 5.96 & 45 & - & - \\
\hline 14 & $\mathrm{CO}_{3}$ & $\mathrm{BDL}$ & 45.0 & 18.14 & - & - & - \\
\hline 15 & $\mathrm{HCO}_{3}$ & 12.0 & 98.0 & 53.78 & - & - & \\
\hline
\end{tabular}

Table 3:- Comparison of results of partial physico chemical analyses with IS 10500 Standards.

\begin{tabular}{|c|c|c|c|c|c|c|c|}
\hline \multirow{2}{*}{$\begin{array}{c}\text { Sl. } \\
\text { No. }\end{array}$} & Parameter & \multicolumn{2}{|c|}{ Concentration of ions } & \multicolumn{2}{c|}{ IS 10500 Standards (1991) } & $\begin{array}{c}\text { Percentage of samples } \\
\text { exceeding permissible limit }\end{array}$ \\
\cline { 3 - 7 } & & Min. & Max. & Average & $\begin{array}{c}\text { Desirable } \\
\text { limit }\end{array}$ & $\begin{array}{c}\text { Permissible } \\
\text { limit }\end{array}$ & - \\
\hline 1 & $\mathrm{EC}$ & 50 & 717 & 262.50 & - & - & - \\
\hline 2 & $\mathrm{pH}$ & 7.34 & 8.43 & 7.84 & 6.5 & 8.5 & - \\
\hline 3 & $\mathrm{TH}$ & 18.0 & 170.0 & 55.56 & 300 & 600 & 5.56 \\
\hline 4 & $\mathrm{~F}$ & $\mathrm{BDL}$ & 1.55 & 0.38 & 1.0 & 1.5 & - \\
\hline 5 & $\mathrm{Fe}$ & 0.13 & 2.44 & 0.64 & 0.3 & 1.0 & - \\
\hline 6 & $\mathrm{Mn}$ & $\mathrm{BDL}$ & 0.21 & 0.06 & 0.1 & 0.3 & - \\
\hline 7 & $\mathrm{Ca}$ & 3.22 & 44.0 & 13.21 & 75 & 200 & - \\
\hline 8 & $\mathrm{Mg}$ & 2.0 & 14.50 & 5.62 & 30 & 100 & - \\
\hline 9 & $\mathrm{Na}$ & 2.50 & 90.0 & 30.37 & - & - & - \\
\hline 10 & $\mathrm{~K}$ & 0.50 & 12.0 & 5.07 & - & - & - \\
\hline 11 & $\mathrm{Cl}$ & 4.0 & 150 & 38.81 & 250 & 1000 & - \\
\hline 12 & $\mathrm{SO}_{4}$ & 3.70 & 31.00 & 12.28 & 200 & 400 & - \\
\hline 13 & $\mathrm{NO}_{3}$ & 0.40 & 21.0 & 5.96 & 45 & 45 & - \\
\hline 14 & $\mathrm{CO}_{3}$ & BDL & 45.0 & 18.14 & - & - & \\
\hline 15 & $\mathrm{HCO}_{3}$ & 12.0 & 98.0 & 53.78 & - & - & \\
\hline
\end{tabular}


Table 4:- Comparison of results of partial physico chemical analysis with $\mathrm{CPCB}^{\#}$ Standards.

\begin{tabular}{|c|c|c|c|c|c|c|}
\hline \multirow[t]{2}{*}{ Sl. No. } & \multirow[t]{2}{*}{ Parameter } & \multicolumn{3}{|c|}{ Concentration of ions } & \multirow{2}{*}{$\begin{array}{c}\text { CPCB } \\
\text { Standards }\end{array}$} & \multirow{2}{*}{$\begin{array}{c}\text { Percentage of samples exceeding } \\
\text { permissible limit }\end{array}$} \\
\hline & & Min. & Max. & Average & & \\
\hline 1 & EC & 50 & 717 & 262.50 & 2000 & - \\
\hline 2 & $\mathrm{pH}$ & 7.34 & 8.43 & 7.84 & $6.5-8.5$ & - \\
\hline 3 & TH & 18.0 & 170.0 & 55.56 & 600 & - \\
\hline 4 & $\mathrm{~F}$ & BDL & 1.55 & 0.38 & 1.5 & 5.56 \\
\hline 5 & $\mathrm{Fe}$ & 0.13 & 2.44 & 0.64 & 1.0 & 16.67 \\
\hline 6 & $\mathrm{Mn}$ & BDL & 0.21 & 0.06 & - & - \\
\hline 7 & $\mathrm{Ca}$ & 3.22 & 44.0 & 13.21 & 200 & - \\
\hline 8 & $\mathrm{Mg}$ & 2.0 & 14.50 & 5.62 & 100 & - \\
\hline 9 & $\mathrm{Na}$ & 2.50 & 90.0 & 30.37 & - & - \\
\hline 10 & $\mathrm{~K}$ & 0.50 & 12.0 & 5.07 & - & - \\
\hline 11 & $\mathrm{Cl}$ & 4.0 & 150 & 38.81 & 1000 & - \\
\hline 12 & $\mathrm{SO}_{4}$ & 3.70 & 31.00 & 12.28 & 400 & - \\
\hline 13 & $\mathrm{NO}_{3}$ & 0.40 & 21.0 & 5.96 & 100 & - \\
\hline 14 & $\mathrm{CO}_{3}$ & $\mathrm{BDL}$ & 45.0 & 18.14 & - & - \\
\hline 15 & $\mathrm{HCO}_{3}$ & 12.0 & 98.0 & 53.78 & - & - \\
\hline
\end{tabular}

${ }^{\#}$ Central Pollution Control Board

$\mathrm{EC}=$ Electric Conductivity ( $\mu \mathrm{m}$ hos $/ \mathrm{cm}), \mathrm{TH}=$ Total Hardness as $\mathrm{CaCO}_{3}, \mathrm{Ca}=\mathrm{Calcium}$ as $\mathrm{Ca}(\mathrm{mg} / \mathrm{L}), \mathrm{Mg}=$ Magnesium as $\mathrm{Mg}(\mathrm{mg} / \mathrm{L}), \mathrm{Na}=$ Sodium as $\mathrm{Na}(\mathrm{mg} / \mathrm{L}), \mathrm{K}=$ Potassium as $\mathrm{K}(\mathrm{mg} / \mathrm{L}), \mathrm{F}=$ Fluoride as $\mathrm{F}(\mathrm{mg} / \mathrm{L}), \mathrm{Fe}=\mathrm{Iron}$ as $\mathrm{Fe}$ $(\mathrm{mg} / \mathrm{L}), \mathrm{Mn}=$ Manganese as $\mathrm{Mn}(\mathrm{mg} / \mathrm{L}), \mathrm{CO}_{3}=$ Carbonates as $\mathrm{CO}_{3}(\mathrm{mg} / \mathrm{L}), \mathrm{HCO}_{3}=\mathrm{Bi}$-carbonates as $\mathrm{HCO}_{3}(\mathrm{mg} / \mathrm{L})$, $\mathrm{SO}_{4}=$ Sulphates as $\mathrm{SO}_{4}(\mathrm{mg} / \mathrm{L}), \mathrm{Cl}=\mathrm{Ch}$ lorides as $\mathrm{Cl}(\mathrm{mg} / \mathrm{L}), \mathrm{NO}_{3}=$ Nitrates as $\mathrm{NO}_{3}(\mathrm{mg} / \mathrm{L}), \mathrm{BDL}=$ Below Detectable Limit $(\mathrm{F}=0.1 \mathrm{mg} / \mathrm{L}, \mathrm{Mn}=0.02 \mathrm{mg} / \mathrm{L})$.

The standard of EC prescribed for drinking water is $2000 \mu \mathrm{mhos} / \mathrm{cm}$ as per CPCB guidelines. Excess EC disturbs the salt and water balance and is responsible for increased blood pressure, kidney problem and diarrhea. EC of the water samples from the study area varies from 50 to $717 \mu \mathrm{mhos} / \mathrm{cm}$ with an average value of $262.50 \mu \mathrm{mhos} / \mathrm{cm}$ and all the samples are within the prescribed limit.

The high or low $\mathrm{pH}$ value results in irritation to the eyes, skin, mucous membranes, swell in hair fibres and gastrointestinal irritation etc (Pradhan and Patra, 2014; WHO, 1996). The $\mathrm{pH}$ value of the water samples in the study area varies from 7.34 to 8.43 and the average is 7.84 which indicates that the water in the study area is slightly alkaline. The $\mathrm{pH}$ limit for drinking water is specified from 6.5 to 8.5 whereas all are within the prescribed limit. In general, $\mathrm{pH}$ of water in the study area is within the specified limits of WHO, IS 10500 and CPCB.

Desirable limit of Total Hardness is $100 \mathrm{mg} / \mathrm{L}$ and maximum permissible limit is $500 \mathrm{mg} / \mathrm{L}$ as per WHO standards. The Total Hardness of water samples from the study area ranges between 18 and $170 \mathrm{mg} / \mathrm{L}$ with an average of 55.56 $\mathrm{mg} / \mathrm{L}$ and all are within the maximum permissible limit.

Calcium concentration in the water samples of study area ranges between 3.22 and $44 \mathrm{mg} / \mathrm{L}$ with an average of $13.21 \mathrm{mg} / \mathrm{L}$. All the water samples are well within the permissible limit of WHO (2004) standards. Similarly, the magnesium concentration ranges between $2 \mathrm{mg} / \mathrm{L}$ and $14.50 \mathrm{mg} / \mathrm{L}$ with an average of $5.62 \mathrm{mg} / \mathrm{L}$. The highest desirable limit as per WHO 2004 standards is $150 \mathrm{mg} / \mathrm{L}$ and all the samples are well within this limit.

The Sodium concentration in water samples varies between 2.50 and $90 \mathrm{mg} / \mathrm{L}$ and all are in prescribed safe limit of $200 \mathrm{mg} / \mathrm{L}$ for drinking water (WHO, 2004).

According to WHO standards, the maximum permissible limit of Potassium in drinking water is $12 \mathrm{mg} / \mathrm{L}$. Concentration of $\mathrm{K}$ ranges from 0.50 to $12 \mathrm{mg} / \mathrm{L}$ and all are within the maximum permissible limit.

The desirable limit of Sulphate is $400 \mathrm{mg} / \mathrm{L}$ (WHO, 2004) and all the samples collected fall under the desirable limit. Sulphate concentration varies from $3.7 \mathrm{mg} / \mathrm{L}$ to $31 \mathrm{mg} / \mathrm{L}$ and an average of $12.28 \mathrm{mg} / \mathrm{L}$. The concentration of nitrate 
varies from 0.4 to $21 \mathrm{mg} / \mathrm{L}$ whereas the WHO and BIS acceptable limit is $45 \mathrm{mg} / \mathrm{L}$. Hence all the samples are within the permissible limit.

Chloride concentration in water samples ranges between 4 and $150 \mathrm{mg} / \mathrm{L}$ with an average of $38.81 \mathrm{mg} / \mathrm{L}$. Acceptable limit of chloride in drinking water as per IS standard is $250 \mathrm{mg} / \mathrm{L}$ and all the samples are within this limit.

Fluoride concentration varies from BDL to $1.55 \mathrm{mg} / \mathrm{L}$ with an average of $0.38 \mathrm{mg} / \mathrm{L}$. The safe limit is $1.5 \mathrm{mg} / \mathrm{L}$ and only one sample exceeds this limit which is collected from Garag Tank.

Permissible limit for Iron is $0.1 \mathrm{mg} / \mathrm{L}$ as per WHO (2004) standards whereas all the samples show Fe concentration above this limit of WHO standard. But as per the IS and CPCB standards, the permissible limit is $1.0 \mathrm{mg} / \mathrm{L}$. According to these standards only 3 samples exceed the Iron concentration limit. One sample collected from a check dam, another from a natural tank and the third one from the T.B.Dam where the wash-off from the hill slope joins the dam water. All these three samples are from the hill bottom. Concentration of Mn varies from BDL to 0.21 $\mathrm{mg} / \mathrm{L}$.

Iron is an essential element in human nutrition and requirement of iron depends on age, sex, physiographical status etc. The largest fraction in humans is present as haemoglobin, myoglobin and haem containing enzymes. Increased iron absorption results in genetic disorder, haemochromatosis-disease that can damage the body's organs, lead to heart disease, liver problem and diabetes. Low iron can lead to anaemia, fatigue, concentration disorder and affects mental development (Verma et. al., 2012; Das, 2014; Yadav and Jamal, 2015).

\section{Conclusions:-}

The surface water samples analyzed were compared with different sets of standards. It is alarming to note that the Fe-content of all samples exceeds the maximum permissible limit given by the World Health Organization (2004). The haphazard dumping of iron ore and waste as well as poor stabilization methods have resulted in the erosion/wash-off during rainy season thereby increasing the Fe-content of surface water bodies.

\section{Recommendations:-}

Considering the presence of excess iron in all the samples when compared to the WHO (2004) standards, the following recommendations are made;

a) Strict compliance of approvals/conditions imposed by the statutory/regulatory authorities.

b) Systematic stock of ore and dumping of waste should be at proper locations and practiced strictly.

c) Effective plans have to be drawn to restore the land affected due to mining by green belt development which would help in many ways to minimize the negative impact on environment.

d) Use of waste for backfilling and brick manufacturing has to be planned and implemented.

\section{Acknowledgements:-}

The authors would like to thank Department of Geology, Karnatak Science College, Dharwad and Department of Studies in Geology, Karnatak University, Dharwad for providing the facilities to carry-out this work. Thanks are also due to Dr. B. K. Wodeyar, Professor (Retired), Dept. of Geology, Karnatak University, Dharwad for his assistance, especially during the field work, and for his continued interest and support. 


\section{References:-}

1. APHA (American Public Health Association) (1985): Standard methods for examination of waters and waste waters, $19^{\text {th }}$ Edn, Washington, D.C.

2. APHA (American Public Health Association) (1998): Standard methods for examination of waters and waste waters, $20^{\text {th }}$ Edn, Washington, D.C.

3. BIS (Bureau of Indian Standards) (1991): Indian standard drinking water specifications (IS 10500-1991).

4. BIS (Bureau of Indian Standards) (2012): Drinking water specifications, $2^{\text {nd }}$ Revision (IS 10500-2012).

5. Das, B. (2014) Environmental impact due to iron ore mining in Chattisgarh. Rec. Res. Sci. Tech., 6 (1): 27-29.

6. Indian Council of Forestry Research and Education (2012) Macro-level environmental impact assessment study report of Bellary district, Karnataka.

7. Indian Council of Forestry Research and Education (2013) Reclamation and rehabilitation plan of Ramanmalai iron ore mine, Bellary district, Karnataka.

8. Pradhan, P. and Patra, S. (2014) Impact of iron ore mining on human health in Keonjhar district of Odisha. IOSR Jour. Econ. Fin., 4 (4): 23-26.

9. Verma, S. R., Chaudhari, P. R., and Satyanarayanan, P. R. S. (2012) Impact of leaching from iron ore mines on terrestrial and aquatic environment. Int. Jour. Envi. Sci., 2 (4).

10. WHO (World Health Organization) (1996) $\mathrm{pH}$ in drinking water - background document for development of WHO guidelines for drinking water quality.

11. World Health Organization (2004) Guidelines for drinking water quality.

12. Yadav, H. L. and Jamal, A. (2015) Impact of mining on water resources in India. Int. Jour. Adv. Res., 3 (10): 1009-1015. 